\title{
TWO-PHASE FLOW IN GEOTHERMAL SYSTEMS
}

FINAL REPORT

\author{
for
}

CONTRACT NO. DE-AC03-35SF15548

July 15, 1986 - April 30, 1987

Co-Principal Investigators:

P. F. Maeder and J. Kestin

Brown University

Providence, RI 02912

\author{
Prepared for the \\ US Department of Energy \\ San Francisco Operations Office \\ Oakland, CA 94612
}

August 1987

Pone:

JAN 311992

OSTI 


\section{DISCLAIMER}

This report was prepared as an account of work sponsored by an agency of the United States Government. Neither the United States Government nor any agency Thereof, nor any of their employees, makes any warranty, express or implied, or assumes any legal liability or responsibility for the accuracy, completeness, or usefulness of any information, apparatus, product, or process disclosed, or represents that its use would not infringe privately owned rights. Reference herein to any specific commercial product, process, or service by trade name, trademark, manufacturer, or otherwise does not necessarily constitute or imply its endorsement, recommendation, or favoring by the United States Government or any agency thereof. The views and opinions of authors expressed herein do not necessarily state or reflect those of the United States Government or any agency thereof. 


\section{DISCLAIMER}

Portions of this document may be illegible in electronic image products. Images are produced from the best available original document. 


\section{TABLE OF CONTENTS}

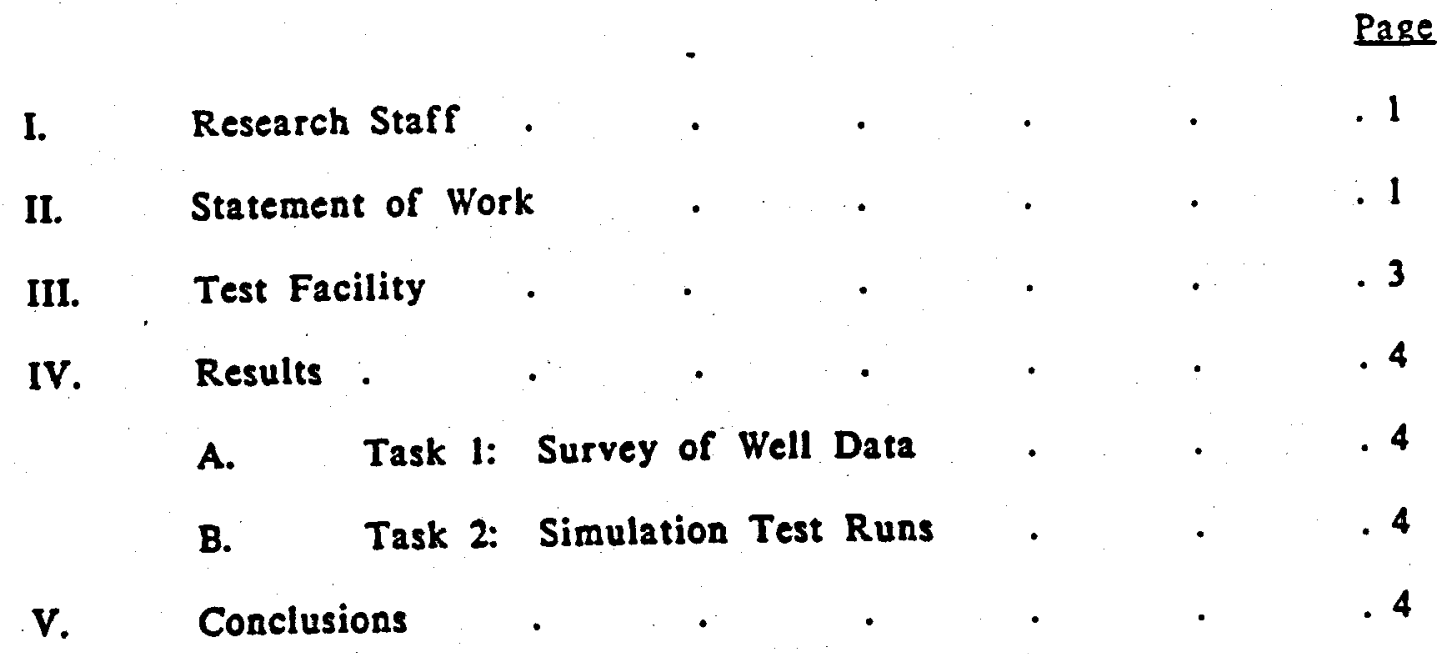

\section{Attachment :}

Report No. TWOPHASE/4: "Theoretical and Empirical Study of Single-Substance, Upward Two-Phase Flow in a Constant-Diameter Adiabatic Pipe, R. N. Laoulache, P. F. Maeder, \& R. DiPippo, Brown University, Providence, RI 02912, May 1987.

\section{DISCLAIMER}

This report was prepared as an account of work sponsored by an agency of the United States Government. Neither the United States Government nor any agency thereof, nor any of their employees, makes any warranty, express or implied, or assumes any legal liability or responsibility for the accuracy, completeness, or usefulness of any information, apparatus, product, or process disclosed, or represents that its use would not infringe privately owned rights. Reference herein to any specific commercial product, process, or service by trade name, trademark, manufacturer, or otherwise does not necessarily constitute or imply its endorsement, recommendation, or favoring by the United States Government or any agency thereof. The views and opinions of authors expressed herein do not necessarily state or reflect those of the United States Government or any agency thereof. 


\section{RESEARCH STAFF}

During the contract period, the following people worked on the project:

Dr. P. F. Maeder, Prof essor of Engineering

Dr. J. Kestin, Professor of Engineering (Research)

Dr. R. DiPippo, Adjunct Professor of Engineering (Research)

Dr. R. N. Laoulache, Research Assistant

Mr. R. Follansbee, Senior Technical Assistant

\section{STATEMENT OF WORK}

The overall object was to establish a full experimental correlation between flashing flows of water-steam in actual geothermal wells and flashing flows of refrigerant-114 (R-114) in the Brown University/DOE Two-Phase Flow Facility.

Task 1: Surver of Well Data

A thorough survey will be made of all existing well-flow data that is pertinent to our research. Ideally the following information should be available on each well.

- Casing profile and completion details.

- Surface roughness in two-phase flow portion.

- Steady (or pseudo-steady) measurements of:

- Mass flow rate (total flow)

- Location of feed zone(s)

- Pressure and remperature at feed zone(s)

- Location of flash horizon

- Pressure and temperature readings at reasonable intervals in the two-phase flow region 


$$
\begin{aligned}
& \text { Wellhead pressure } \\
& 0 \quad \text { Wellhead dryness fraction }
\end{aligned}
$$

Methods and instrumentation used to obtain data.

We expect that only a subset of this list will actually be available for any particular well.

We will look for wells in which the flash horizon occurs in the final production casing, not in a slotted liner or in the formation, because this condition can be most easily simulated in our straight-tube test section. This may require data on wells that are flowed in a throttled-back mode (i.e., low flow rates and shallow flash depths). Consequently, the test section will probably require modification to accept a smaller diameter tube (i.e, smaller than the current 2-in diameter one) and necessitate the fabrication of a new venturi insert to accommodate flow rates less than $1 \mathrm{~kg} / \mathrm{s}$.

A number of well logs have already been obtained in anticipation of this work that had been scheduled-for the third year of the original work plan. We have data on several wells in New Zealand including: Kawerau wells KA-10 and -16; Ngawha wells NG-3, -11, -12, and -13; Broadlands wells BR-11 and -21; and Mokai well MK-2. We expect to receive new data obtained by the Los Alamos National Laboratory (Dr. R. Hanold) on wells in the Miravalles field in Costa Rica. A set of data exists on well PGM-10 and measurements are scheduled on wells PGM-5 and -11 during June 1986. All this data, and others, will be made available to us by LANL for this study.

\section{Task 2: Simulation Test Runs}

We will base the redesign of the test section on our similarity analysis. The flow conditions upstream of the flash point and at the flash point will be chosen to match those in the selected well. The direct 
measurements of pressure and temperature in the test section may then be compared with logs from the actual well, again with the aid of the similarity analysis.

With a link established between the laboratory test and the actual well, one could then modify the laboratory test section (say, to simulate a larger diameter well in the same field) and be able to predict the performance of the new proposed well based on laboratory measurements using R-114. This latter suggestion is not a specific task for this phase of the project, but could be undertaken in the future.

A demonstration of this type would have an important consequence; namely, that relatively inexpensive experiments in our facility could be performed so as to determine optimum well completions that would lead to maximum productivity. Since geothermal well costs can run as high as $\$ 2$ million/well, the savings that would accrue would be substantial.

\section{TEST FACILITY}

One of the uses to which the Two-Phase Flow Facility can be put is the simulation of flow conditions in an actual geothermal well. Similarity analysis between $R-114$ and steam-water mixtures reveals that it is not possible to achieve exact similarity, but that a reasonably good approximation should be possible. Hence, series 5 and 6 were conducted to confront the similarity theory with two sets of measurements: one from an actual flowing geothermal well and one from the test facility, configured to match the well as closely as possible according to the theory.

A considerable modification of the test facility was required. The entire glass test section was replaced with a commercially available $0.0254 \mathrm{~m}$ copper tube. The test section was completely insulated and additional probes 
were added along the test section to permit an accurate determination of the flash horizon since this could no longer be ascertained visually. Similarity analysis showed also that the mass flow rate had to be reduced drastically. This necessitated the fabrication of a new venturi flow meter. The new one was similar to the previous venturi meters used for different mass flow rates. The mass flow rate measured by the new venturi flow meter was checked against the flow rate calculated from the level change of R-114 in the accumulator which is maintained under a constant pressure supplied by the booster. The discrepancy was less than $0.8 \%$ and no correction from the standard ASME flow formula was required.

IV. RESULTS

A. Task l: Survey of Well Data

The results of this part of the project are given in the attached report, TWOPHASE/4, beginning on p. 101. The survey of geothermal well data is shown in Table 5, p. 132; the data for the well chosen for laboratory simulation, NG-11, is shown in Table 6, p. 133. Although this well was not ideally suited for simulation in our facility, it represented the best compromise.

B. Task 2; Simulation Test Runs

Two series of tests, Series 5 and 6, were conducted. These are discussed in detail in the attached report beginning on p. 108. The results of the tests are shown in Tables 7-10, pp. 134-137.

\section{v. CONCLUSIONS}

Our experiments show that the similarity theory developed in our laboratory during previous phases of this research project can be used to 


\section{5}

predict accurately the pressure gradient in the two-phase region of a flowing geothermal well using laboratory measurements on R-114. This conclusion holds even when the actual geothermal well contains significant amounts of noncondensable gases. In this case, however, corrections must be introduced to account for the partial pressure of the gases.

Following the last series of experiments, the two-phase flow facility was dismantled. The entire apparatus is available to parties interested in pursing this line of research. More information can be obtained by contacting Mr. Carl Cometta, Division of Engineering, Box D, Brown University, Providence, RI 02912, tel: (401) 863-2319. 